\title{
Obesity-associated Pathways of Anthocyanins
}

\author{
Elif YILDIZ ${ }^{1 \star ~(D), ~ M e t i n ~ G U L D A S ², ~ P i n a r ~ E L L E R G E Z E N ³ ~}$, Asli Gul ACAR4, Ozan GURBUZ ${ }^{1}$
}

\begin{abstract}
Anthocyanins have a great potential for human health, as a sub-group of phenolic compounds. Interactions of anthocyanin involved in digestion and thus in obesity consist of inhibition of pancreatic lipase, regulation of lipolysis and lipogenesis, activation of an activated protein kinase enzyme, controlling of digestion hormones (leptin, insulin, ghrelin, cholecystokinin, GIP, GLP-1). Anthocyanins are the compounds that can control metabolic syndrome and obesity by ameliorating lipid metabolism, increasing energy expenditure, suppressing food intake and inhibiting lipid absorption. In addition, the interactions with other compounds during the processing and/or in the intestinal canal can change their absorption capability and bioavailability. Activation of mitogen-activated protein kinase and cyclooxygenase (COX) enzymes, inflammatory cytokines signaling, free-radical scavenging activity are among the primary functions of anthocyanins playing role in the basic metabolic pathways. Anthocyanins also interact with gut microbiota that plays a role in many metabolic pathways. In the review, the effects of anthocyanins on the obesity-associated mechanisms in the metabolism are considered and summarized under the light of recent researches.
\end{abstract}

Keywords: anti-obesity; anthocyanins; digestion; lipid metabolism; metabolic pathways.

Practical Application: Effects of Anthocyanins in metabolic pathways over obesity.

\section{Introduction}

Anthocyanins are food components that are very important in terms of human health especially available in fruits and vegetables that are prominent with their attractive colors. They are mainly flavonoid pigments whose colors vary from orange to blue and violet (Zhang et al., 2019a). The anthocyanins act by various mechanisms in protection from various specific diseases and in stopping the progression of the diseases. They are compounds that are highly capable of reacting with many chemical components. It has been found to be involved in many complex metabolic interactions in human metabolism. Anthocyanins are generally effective in inhibiting a-glucosidase, lipase, $a$-amylase enzymes, lowering glucose levels, regulating insulin secretion, and preventing insulin resistance (Habtemariam \& Varghese, 2014). They possess anticancer (Liang et al. 2019) anti-tumoral (Reboredo-Rodríguez 2018), anti-atherosclerotic (Long et al., 2018), anti-inflammatory (Perez-Meseguer et al. 2019), anti-microbial (Bukhari et al. 2019) and anti-obesity effects on human health and are the chemical componds that prevent neuronal and cardiovascular diseases (Yang et al., 2019, Watson et al., 2019, Zhang et al., 2019b). Anthocyanins have anti-obesity effects of blood lowering leptin levels by means of the modulation of adipocytokine secretion and lipid metabolism in the adipose tissue (Tucakovic et al., 2018).

Obesity and overweight are described as excessive fat accumulation or abnormal that causes significant health risks by the WHO (World Health Organization, 2018). A person who has a BMI (Body Mass Index) of $30 \mathrm{~kg} / \mathrm{m}^{2}$ or more is assumed as obese, while a person with a BMI equal to or more than $25 \mathrm{~kg} / \mathrm{m}^{2}$ is accepted as overweight. Obesity and overweight obesity are the main risk sources for various chronic diseases such as cancer, diabetes, cardiovascular diseases, etc. Obesity and overweight were initially considered to be a social problem that was prevalent only in wealthy countries with excessive food consumption. Today, however, it is identified as a rapidly growing global problem in low- and middle-income countries, especially in urban areas (World Health Organization, 2018).

In this review, the interactions of anthocyanins, which are abundant in fruits and vegetables, on the metabolism from past to present, especially in anti-obesity, are investigated and discussed.

\section{Anthocyanins}

Anthocyanins are generally present in the skin of plants but can also be found in their flesh, and their amount increases during ripening stage (Clifford, 2000). They are water-soluble pigments, glycosides or acyl glycosides of anthocyanidins that are flavylium (2-phenyl benzo pyrylium) salts (Zhang et al., 2019c). In general, anthocyanins are heterosides containing an anthocyanidin (aglycone) derived from the 2-phenyl benzo pyrylium (flavylium) ring which is different form as methoxylated (hydroxylated), that is part of the one or more sugar molecules which can be acylated afterward by aromatic or aliphatic organic acids. In nature, most of the anthocyanins are derived from the six aglycone molecules known as petunidin, malvidin, pelargonidin, 
delphinidin, peonidin and cyanidin (Figure 1). It has been found approximately 539 derivates of anthocyanins available in the plants as mentioned by Žilić et al. (2019). Cyanidin-3-glucoside is one of the most known anthocyanins available in the fruits and vegetables.

In respect of their health benefits, usage and application in foods, interaction capability is a critical factor and changes depending on amount, $\mathrm{pH}$, light, temperature, metallic ions, presence of oxygen, proteins, enzymes, and other phenolics compounds (Kasote et al., 2019). Interaction capability of anthocyanins is mainly based on their conjugated double bonds. Conjugated bonds in the molecule cause multi-functionality in terms of chemical reactions and mean that the single and double bonds interchangeable. This capability allows that the electrons can be delocalized throughout the entire molecule and thus be shared by the other atoms. Therefore, the delocalized electrons can be replaced among the atoms in the whole molecule system. On the other hand, the conjugate bonds of anthocyanins are responsible for their different colors appeared as purple, blue and red. Because of the ionic nature of the anthocyanin molecule, their color changes can be affected by the $\mathrm{pH}$ of the product or environment. Furthermore, their solubility in the aqueous media also changes depending on the $\mathrm{pH}$. In slightly acidic to neutral conditions, blue quinoidal bases are formed by de-protonation while colorless hemiketal forms are formed by hydration. Under the acidic conditions, cations of red flavylium are produced intensively (Turturică et al., 2015; Khoo et al., 2017).

Anthocyanins have significant free radical-scavenging and antioxidative properties by hydrogen (electron) donation ability belonging to flavonoid molecule (Fascella et al., 2019). They activate the genes responsible for the enzyme production in order to protect DNA by reducing oxidative stress and the formation of endogenous reactive oxygen species. The antioxidant enzyme activity for the enzymes such as superoxide dismutase can be increased by this mechanism (Bonetta, 2018; Gonçalves et al., 2018; Dziadek et al., 2019; Oracz et al., 2019).

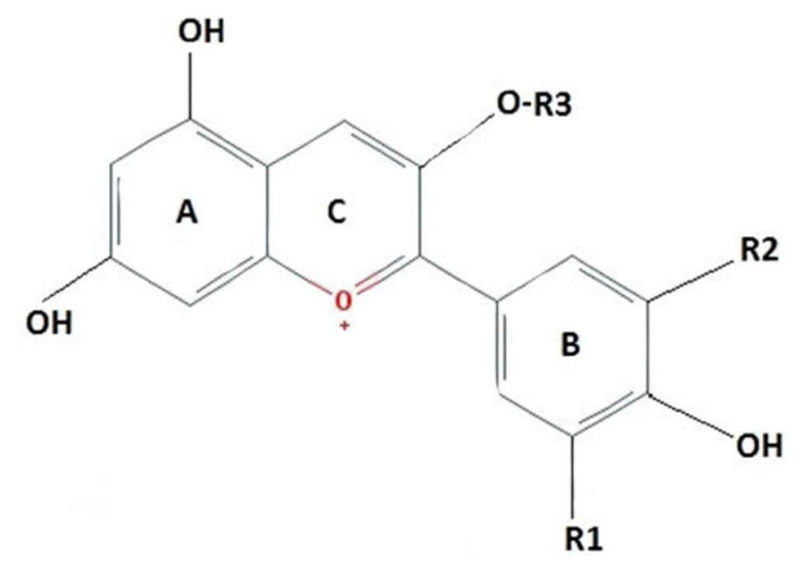

Figure 1. Chemical structure of the common anthocyanins. Cyanidin $R_{1}(\mathrm{OH}), R_{2}(\mathrm{H}), \mathrm{R}_{3}$ (Sugar); Malvidin $\mathrm{R}_{1}\left(\mathrm{OCH}_{3}\right), \mathrm{R}_{2}\left(\mathrm{OCH}_{3}\right), \mathrm{R}_{3}($ Sugar $)$; Peonidin $R_{1}\left(\mathrm{OCH}_{3}\right), R_{2}(\mathrm{H}), R_{3}$ (Sugar); Delphinidin $R_{1}(\mathrm{OH}), R_{2}(\mathrm{OH})$, $R_{3}\left(\right.$ Sugar); Pelarganidin $R_{1}(H), R_{2}(H), R_{3}\left(\right.$ Sugar ); Petunidin $R_{1}\left(O_{3} H_{3}\right)$, $R_{2}(\mathrm{OH}), R_{3}$ (Sugar). The Aromatic A-ring condensed with non-aromatic $C$-ring and other aromatic $B$-ring that forming a carbon-carbon bonding.
Anthocyanins have many different functions in plants. They are antioxidants, protect the plant from UV light, are a defense mechanism and are very important for pollination and reproduction. The color of many flowers originates from anthocyanins, and is important for attracting insects. Bee-pollination species are more abundant in plants such as Primulaceae containing delphinidine-anthocyanins, while other anthocyanins are preferred by wasps or birds. Cyaninidin-3-glucoside, a common anthocyanin, protects the plant against some larvae. Other anthocyanins have similar activities. As an antioxidant, anthocyanins protect plants from free radicals (formed by daylight or plant degradation) that break down DNA and cause cell death. There are indications that anthocyanins promote health as antioxidants, reducing the risk of chronic heart disease, improving visual and antiviral activity. However, these claims have not been scientifically proven. Anthocyanins are important antioxidants, but their impact on human health is not fully understood (Delgado-Vargas \& Paredes-Lopez, 2002).

\section{Obesity}

Obesity, defined as the increase in adipose tissue, occurs as a result of disturbance in energy balance, and is an important health problem that is rapidly increasing all over the world (Krassas et al., 2003). Insulin resistance (IR) is associated with many metabolic disorders including impaired insulin releasing, non-insulin dependent diabetes, cardiovascular diseases hypertension and dyslipidemia etc. However, with the pathogenesis of IR developing in obesity related mechanisms are not fully understood (Lee et al., 2009). Insulin and glucagon levels of glucose in equilibrium is a narrow range under normal physiological conditions. It was thought to have been managed. Today this understanding the presence of a more complex multihormonal system has changed direction. Both glucose metabolism this multihormonal regulates both food intake and insulin and amylin released from the pancreas, glucagon-like peptide-1 (GLP-1), ghrelin and glucose-dependent insulinotropic polypeptide (GIP) secreted from the intestinal tract, adipokines (leptin, adiponectin, visfatin, resistin and adipsin) secreted from adipose tissue have an important place (Aronoff et al., 2004).

\section{Obesity-anthocyanin interactions}

The mechanisms involved in preventing obesity due to anthocyanins can be classified under five pathways. These mechanisms are inhibition of lipid absorption, increasing of energy expenditure, regulation of lipid metabolism, regulation of gut microbiota and controlling of food intake. The mechanisms led to anti-obesity effect and their interactions connected with obesity metabolism have investigated by in vitro experiments and clinical trials with test animals (Table 1).

\subsection{Hunger and satiety}

The hunger is controlled by hypothalamus present in the human brain. The neurons available in the hypothalamus are responsible for controlling food intake and energy expenditure. There are two specific neuron types in the hypothalamus: anorexigenic or appetite-suppressing (Pro-opiomelanocortin) neurons (1) and orexigenic or appetite provocative neuropeptide 
Yildiz et al.

Table 1. Anti-obesity mechanisms and effects on the body parameters of the anthocyanins.

\begin{tabular}{|c|c|c|c|c|}
\hline Fruit/Vegetable & Active Compound & Mechanism & Body Parameter & Ref. \\
\hline $\begin{array}{c}\text { Blueberry } \\
\text { (Vaccinium Ashei, } \\
\text { Vaccinium corymbosum) }\end{array}$ & $\begin{array}{l}\text { Cyanidin-3-galactoside, } \\
\text { Cyanidin-3-arabinoside, } \\
\text { Delphinidin-3-arabinoside, } \\
\text { Delphinidin-3-galactoside, } \\
\text { Petunidin-3-glucoside, } \\
\text { Petunidin-3-arabinoside, } \\
\text { Malvidin-3-galactoside, } \\
\text { Malvidin-3-glucoside }\end{array}$ & $\begin{array}{l}\text { Regulate lipid metabolism, } \\
\text { Resolve inflammation }\end{array}$ & $\begin{array}{c}\text { Glucose } \uparrow \text {, } \\
\text { Triglyceride (TG) } \\
\text { Accumulation } \downarrow \text {, } \\
\text { Cholesterol } \downarrow \text {, } \\
\text { Insulin secretion } \downarrow \text {, } \\
\text { Leptin secretion } \downarrow\end{array}$ & $\begin{array}{c}\text { Stull (2016), } \\
\text { Wu et al. (2016b) } \\
\text { Xie et al. (2016) }\end{array}$ \\
\hline $\begin{array}{l}\text { Blackcurrant } \\
\text { (Ribes nigrum) }\end{array}$ & $\begin{array}{l}\text { Delphinidin-3-glucoside, } \\
\text { Delphinidin-3-orutinoside, } \\
\text { Cyanidin-3-glucoside, } \\
\text { Cyanidin-3-rutinoside }\end{array}$ & Controlling weigh gain & Adipogenic genes $\downarrow$ & $\begin{array}{l}\text { Benn et al. (2014) } \\
\text { Esposito et al. (2015) }\end{array}$ \\
\hline $\begin{array}{c}\text { Cranberry } \\
(\text { Vaccinium oxycoccos })\end{array}$ & $\begin{array}{l}\text { Cyanidin-3-galactoside, } \\
\text { Cyanidin-3-arabinoside, } \\
\text { Peonidin-3-galactoside, } \\
\text { Peonidin-3-arabinoside }\end{array}$ & $\begin{array}{l}\text { Controlling weigh gain } \\
\text { Insulin resistance } \downarrow\end{array}$ & Glucose $\downarrow$ & $\begin{array}{l}\text { Wilson et al. (2010), } \\
\text { Wang et al. (2015) }\end{array}$ \\
\hline $\begin{array}{c}\text { Raspberry } \\
\text { (Rubus idaeus) }\end{array}$ & $\begin{array}{l}\text { Cyanidin-3-glucoside, } \\
\text { Cyanidin-3-sophorosides, } \\
\text { Pelargonidin-3-glucosides, } \\
\text { Pelargonidin-3-diglucoside, } \\
\text { Pelargonidin-3-rutinocides, } \\
\text { Pelargonidin-3-sambubiosides }\end{array}$ & $\begin{array}{c}\text { Energy expenditure } \uparrow, \\
\text { Lipid accumulation } \downarrow \text {, } \\
\text { Inflammatory response } \downarrow\end{array}$ & $\begin{array}{c}\text { Cholesterol } \downarrow \text {, } \\
\text { Adinopectin } \uparrow, \\
\text { Insulin sentivity } \uparrow, \\
\text { IL- } 6 \downarrow\end{array}$ & $\begin{array}{l}\text { Bonetta (2018), } \\
\text { Jeong et al. (2014), } \\
\text { Sardo et al. (2016), } \\
\text { Overall et al. (2017), } \\
\text { Zhao et al. (2018) }\end{array}$ \\
\hline $\begin{array}{c}\text { Mulberry } \\
\text { (Morus australis P.) }\end{array}$ & $\begin{array}{l}\text { Cyanidin-3-glucoside, } \\
\text { Cyanidin-3-rutinoside, } \\
\text { Pelarginidin-3-glucose }\end{array}$ & $\begin{array}{c}\text { Ameliorate lipid } \\
\text { metabolism, } \\
\text { Inhibition of food intake }\end{array}$ & $\begin{array}{c}\text { Glucose } \downarrow \text {, } \\
\text { Leptin secretion } \downarrow\end{array}$ & Wu et al. (2016b) \\
\hline $\begin{array}{l}\text { Siberian Ginseng } \\
\text { (Eleutherococcus } \\
\text { senticosus) }\end{array}$ & Cyanidin-3-glucoside & $\begin{array}{c}\text { Regulate lipid metabolism, } \\
\text { Energy expenditure } \uparrow\end{array}$ & $\begin{array}{l}\text { AMPK (Activated protein } \\
\text { kinase enzyme) regulation }\end{array}$ & $\begin{array}{l}\text { Lee et al. (2013), } \\
\text { Overall et al. (2017) }\end{array}$ \\
\hline $\begin{array}{c}\text { Aronia } \\
\text { (Aronia melanocarpa) }\end{array}$ & $\begin{array}{l}\text { Cyanidin-3-galactoside, } \\
\text { Cyanidin-3-glucoside, } \\
\text { Cyanidin-3-arabinoside, } \\
\text { Cyanidin-3-xyloside }\end{array}$ & $\begin{array}{l}\text { Modulate adipogenesis } \\
\text { related functions, } \\
\text { Lipid metabolism } \\
\text { regulation }\end{array}$ & $\begin{array}{l}\text { Energy expenditure } \uparrow, \\
\text { Suppress food intake }\end{array}$ & Xie et al. (2016) \\
\hline $\begin{array}{l}\text { Red Grapes } \\
\text { (Vitis vinifera) }\end{array}$ & $\begin{array}{l}\text { Cyanidin-3-glucoside, } \\
\text { Delphinidin-3-glucoside, } \\
\text { Malvidin-3-glucoside, } \\
\text { Peonidin-3-glucoside, } \\
\text { Petunidin-3-glucoside }\end{array}$ & $\begin{array}{l}\text { Controlling weight gain, } \\
\text { Inflammatory response } \downarrow\end{array}$ & Increased glucose tolerance & $\begin{array}{l}\text { Chuang et al. (2012), } \\
\text { Budić-Leto et al. (2018) }\end{array}$ \\
\hline $\begin{array}{c}\text { Black Carrots } \\
\text { (Daucus carota L.) }\end{array}$ & $\begin{array}{l}\text { Cyanidin-3-rutinoside, } \\
\text { Malvidin-3,5-diglycoside, } \\
\text { Delphinidin-3-glucoside }\end{array}$ & $\begin{array}{l}\text { Hepatic triglyceride } \\
\text { accumulation } \downarrow\end{array}$ & $\begin{array}{c}\text { Energy expenditure } \uparrow, \\
\text { Regulation lipid } \\
\text { metabolism }\end{array}$ & Park et al. (2015) \\
\hline $\begin{array}{l}\text { Purple Sweet Potato } \\
\text { (Ipomoea Batatas) }\end{array}$ & $\begin{array}{l}\text { Cyanidin-3-glucoside, } \\
\text { Peonidin-3-glucoside }\end{array}$ & $\begin{array}{l}\text { Lipid metabolism } \\
\quad \text { regulation, } \\
\text { Hepatic triglyceride } \\
\text { accumulation } \downarrow\end{array}$ & $\begin{array}{l}\text { Leptin secretion } \downarrow \text {, } \\
\text { Adipogenic factors } \downarrow\end{array}$ & $\begin{array}{l}\text { Andre et al. (2007), } \\
\text { Poudyal et al. (2010), } \\
\text { Ju et al. (2011), } \\
\text { Zhang et al. (2015) }\end{array}$ \\
\hline $\begin{array}{c}\text { Red Radish } \\
\text { (Raphanus raphanistrum } \\
\text { subsp. Sativus) }\end{array}$ & $\begin{array}{l}\text { Cyanidin-3-glucoside, } \\
\text { Pelarginidin-3-glucoside }\end{array}$ & $\begin{array}{l}\text { Lipid metabolism } \\
\text { regulation }\end{array}$ & $\begin{array}{l}\text { Triglyceride (TG) } \\
\text { accumulation } \downarrow\end{array}$ & Lee et al. (2018) \\
\hline
\end{tabular}

(Agouti-related peptide) neurons (2). The body energy level is controlled by means of the signals transmitted by these neurons (Roh \& Kim 2016).

The level of gastrointestinal satiety is controlled by the main signal produced from the digestive tract. Thus, a full stomach and intestine provoke satiety, by means of the vagus nerve connecting to the hypothalamus. Furthermore, the enteric hormone cholecystokinin induces satiety, while the hormone ghrelin stimulates the appetite. When the level of nutrients such as amino acids and glucose are increased in the blood, concentrations of the hormones such as cholecystokinin, insulin, and glucagon are elevated (Ştefănescu (Braic) et al., 2018; Zhao et al., 2018).

Food intake is essentially controlled by the the hormones named insulin, and ghrelin with cholecystokinin in the body. 
Insulin, ghrelin and cholecystokinin with glucagon-like peptide-1 (GLP-1) are released by the signals produced from adipose tissue, pancreas and digestive tract (stomach and intestine), respectively (Ştefănescu (Braic) et al., 2018).

\subsection{Metabolic pathways in obesity}

\section{Inhibition of pancreatic lipase enzyme}

The main inhibition effect of the pancreatic lipase enzyme is preventing lipid absorption. This mechanism is mainly depended on decreasing energy intake into the body. Over-consumption of fat during daily diet causes mainly hyperlipidemia and triggers to increase the weight of adipose tissue. In addition, the occurrence of some significant metabolic diseases is related to the increase in fat tissue. Pancreatic lipase enzyme is required for the dietary fat absorption. Therefore, it is important to inhibit pancreatic lipase enzyme in order to reduce obesity development (Vijayaraj et al., 2019). Anthocyanin-rich fruits and vegetables contain significant anthocyanins that are able to inhibit pancreatic lipase enzyme, thus, some fruits and vegetables rich in anthocyanins have significant effects on preventing obesity. Due to, high content of anthocyanin, it has been declared that many fruits such as pomegranate and blood orange, have a very high pancreatic lipase inhibiting activity (Xie et al., 2018).

In the research in which the effect of litchi flower extract in the Mediterranean diet containing anthocyanin-rich fruit and vegetables was investigated, it was determined that the extract samples have a suppressive effect on pancreatic lipase. In the researches in which some anthocyanin-containing fruits were used, it was found that pomegranate and blood orange juices have significant pancreatic lipase inhibition due to the high anthocyanin content (Chen et al., 2018; Xie et al., 2018; Vijayaraj et al., 2019). In another research, black rice extract containing cyanidin 3-glucoside and peonidin 3-glucoside anthocyanins in the arrest of cholesterol absorption in Caco-2 cells has been tested. It was found that the pancreatic lipase was inhibited by the experimental extract and reduced the cholesterol absorption up to $58 \%$. It has also been observed that the adsorption by dose-dependent recombinant actions has also been reduced by the two anthocyanins tested. The hypolipidemic activity of cyanidin 3-glucoside was determined, is caused by its regulatory role on the lipogenic enzymes available in hypercholesterolemic erythrocytes (Chen et al., 2018; Li et al.2018).

\section{Activated protein kinase enzyme}

The main mechanism of this enzyme on energy metabolism is to increase energy expenditure in the cell. The mechanism is mainly based on the stimulation of fatty acid oxidation and mitochondrial biogenesis. Activated protein kinase enzyme is one of the most significant enzymes that play a role in the energy balance of the human body. The main action of activated protein kinase enzyme is to preventing of triglyceride synthesis, stimulating fatty acid oxidation and exposing of energy due to accelerated reactions seen in the mitochondria (Chen et al., 2018; Li et al.2018).

As known, energy expenditure is managed by mitochondria in the cell structure. Activated protein kinase enzyme (AMPK) is the main factor to control signals responsible for obtaining energy. AMPK causes to increase in the expression of the genes (PPARgcla) which encode the regulator of mitochondrial biogenesis as mentioned by Garcia \& Shaw (2017). The mission of AMPK in the cell is inhibition of the lipid metabolism. The inhibition of lipid metabolism occurs via provoking the metabolic stress and the formation of cytokines which are formed by adipocytes such as adiponectin and leptin. In addition, AMPK enzyme prevents triglyceride synthesis, increases fatty acid oxidation and provokes the mitochondrial cycle. Therefore, if the AMPK enzyme is activated, hypertriglyceridemia and deposition of triglycerides in the muscle tissue and liver decrease. There are also uncoupled mitochondrial proteins regulate thermogenesis which is the process of heat production in the organism (Chen et al., 2018; Iizuka et al., 2018; Kang 2018; Li et al., 2018; Xie et al., 2018).

In the comprehensive study conducted on the mice, four different diets ( $2 \%$ of dextrin, $2 \%$ of black carrot extracts, $2 \%$ of black carrot fermented with Lactobacillus plantarum and $2 \%$ of black carrot fermented with Aspergillus oryzae) were tested versus the control group fed with a high-fat diet including $2 \%$ of dextrin. At the end of the observation period, fat tissue ratio and weight gain, blood cholesterol, and triglyceride levels decreased compared to the control group fed with black carrot extracts, black carrot fermented with Lactobacillus plantarum and black carrot fermented with Aspergillus oryzae. It has been mentioned that AMPK (pAMPK) and Acetyl CoA carboxylase are responsible for the positive changes (Park et al., 2017). Some proteins in the mitochondria present in the fat tissues are responsible for the thermogenesis. Thermogenesis is a metabolic process during which the human body burns calories which are obtained from energy compounds to produce heat (Kang, 2018; Lemecha et al., 2018). In the mice fed with black soybean extract including the anthocyanins listed as $6.2 \%$ of epicatechin, $9.2 \%$ of cyanidin-3-glucoside, and $39.8 \%$ of procyanidin for 14 weeks; black soybean extract caused to stop the fat accumulation by regulation of proteins in the mesenteric fat pouch. Uncoupling protein 1 (UCP-1) in brown adipose tissue and uncoupling protein 2 (UCP-2) in white adipose tissue are the proteins playing role in the mitochondrial cycle and have been shown to regulate protein expression levels and genes (Kanamoto et al., 2011). In the mice fed with purple sweet potatoes containing $200 \mathrm{mg} / \mathrm{kg}$ anthocyanin per day, the decrease in the weight gain was observed. Furthermore, it was seen that the hepatic triglyceride accumulation and serum lipids are lowered. Anthocyanin fraction led to an increase in AMPK phosphorylation and a decrease in the levels of SREBP-1, ACC, and FAS (Hwang et al., 2011)

\section{Lipolysis and lipogenesis}

If the amount of energy-giving compounds in the body is higher than the consumption of those compounds, the fat accumulation in the body is unavoidable. Therefore, lipid metabolism should be sustained in balance. Two enzymes as acetyl-CoA carboxylase and fatty acid synthase are significant players in the regulation of lipid metabolism (Chen et al., 2018; Iizuka et al., 2018; Li et al., 2018, Xie et al., 2018). In the regulation of lipid metabolism, lipolysis and lipogenesis are 
major active mechanisms. If lipolysis does not remain in force effectively, dyslipidemia occurs. The lipolysis causes to reduce fat deposition while lipogenesis leads to fat accumulation. The fatty acids formed as a result of lipolysis are the compounds open to oxidation. As declared in recently, lipid metabolism can directly be influenced by the anthocyanins available in the diet. In the research that has been done to investigate the consumption of anthocyanins on lipid metabolism, the mice were nourished with a high-fat diet and given black soybean extract (cyanidin-3-glucoside, 10mg/g) for 6 weeks. It has been observed that fatty acid compositions in rats fed with black soybean were changed and decreased. It was seen that this decrease in the level of fatty acids can help to prevent the inflammation in the body (Sato et al., 2015). It has been mentioned that diet with $10 \%$ and $20 \%$ of adzuki nuclei and Aronia melanocarpa extract containing a high level of anthocyanin, led to regulation of hepatic triglyceride and serum contents in C57BL/6 rats fed a high-fat diet for 10 weeks (Kim et al., 2016; Park et al., 2017).

The role of anthocyanins on obesity is significant due to the regulating effect on lipid metabolism. Black carrot fermented with Aspergillus oryzae and cranberry extract has been found to reduce gene and mRNA expression in the oxidation mechanism for fatty acids and enzyme fatty acid synthase (Lemecha et al., 2018). Cheng et al. (2014) 's, research made with mice, they observed that feeding with lettuce extract containing cyanidin-3 glucoside caused to lower lipid level in the liver after 4 weeks. In another study made with mice fed by Queen Garnet juice and a pure cyanidin-3 glucoside, it has been determined that both of the diets caused to reduce the abnormal metabolic reactions due to high-fat consumption (Bhaswant et al., 2015). Sweet cherry is a fruit that mainly contains anthocyanins including cyanidin 3-rutinoside, cyanidin 3-(2G-glucosyl-rutinoside) and pelargonidin 3 -rutinoside. It has found that sweet cherry anthocyanins on the mice reduced to weight gain between 5 to $11 \%$.

In addition, the diet with sweet cherry anthocyanins decreased the dimensions of epididymal adipocytes and levels of serum lipids in 3T3-L1 cells about $30 \%$ as mentioned by Wu et al., (2014). In another study, it was found that the bodyweight of the mouse was reduced by approximately $19 \%$ by consuming currant anthocyanins (Wu et al., 2016a).

\subsection{Hormone activities in obesity}

\section{Insulin activity}

Fat accumulation and inflammation are the changes that cause damage in glucose metabolism and insulin resistance. That's why disrupted glucose metabolism leads to an increase in tissue damage and inflammation. Finally, endothelial dysfunction occurs (Frueh et al., 2013). The anti-diabetic role of anthocyanins is based on the inhibition of some enzymes such as a-glucosidase and $\alpha$-amylase available in the pancreas (Kalita et al., 2018). The anti-diabetic effect of anthocyanins can be seen just like traditional anti-diabetic drugs. In their activation mechanisms, the carbohydrate digestion is being prevented in the gut by reducing the level of glucose available in the blood. Anthocyanins mainly including cyanidin, delphinidin, pelargonidin, and petunidin glycosides have inhibition effect on the enzymes that response from the digestion of the carbohydrates (Belwal et al., 2017).
In recent years, comprehensive studies regarding insulin resistance on human adipocytes cells (3T3-L1), muscle cells (L6 myotubes), $\beta$-cells and satellite cells available in the rodents pancreas, the rat liver cells (H4IIE) and the hepatocytes (HepG2 cells), have been done in-vitro conditions (Belwal et al., 2017). It has been found that anthocyanins can lead to raising glucose level and insulin sensitivity in the adipose tissues and the muscles, and thus can regulate insulin resistance for diabetics. Furthermore, anthocyanins can suppress the lipogenic factors that play an effective role in the adipocyte cells (Scazzocchio et al., 2011).

\section{Leptin activity}

Leptin plays a significant role among these neuron cells. The main hormone related to satiety is leptin. Leptin is synthesized and secreted mainly by fat cells called adipocytes of the white adipose tissue. Its main function is regulating energy balance. The leptin receptors are mainly found in the hypothalamus, which is known to act in controlling metabolic rate and food intake. It is also produced by brown adipose tissue. Leptin is satiety controlling hormone. Leptin concentration increases or decreases in plasma. Normally, if the body fat mass increases, the level of leptin in blood also increases. If the level of leptin is increased, body weight also reduces depending on the low food intake, increased energy expenditure and metabolic rate (Pan \& Myers, 2018).

Leptin resistance is a disfunctioning of leptin mechanism that results in overweight and obesity (Wu et al., 2013). As the most common two reasons for obesity are of leptin resistance and damage of adipocytokines (Lazar \& Saltiel, 2006). Therefore, controlling of leptin resistance in obesity treatment is an important strategy.

The purified cyanidin 3-glucoside used in the diet of the rats has found to stimulate adipocytokine (leptin and adiponectin) secretion in the adipose tissue (Nemes et al., 2019). But, there are also the findings in which the different correlation between leptin and adiponectin was found. For example, adiponectin levels in the mice fed with the anthocyanin-rich foods increased while leptin secretion is decreased (Wu et al., 2016b, 2018).

\section{Glucagon-like peptide-1 (GLP-1) activity}

Glucagon-like peptide-1 (GLP-1), which enhances postprandial insulin release in a glucose-dependent trait, is a peptide hormone that is secreted by intestinal epithelial L-cells in response to food, hormonal and neural stimuli (Meier \& Nauck 2005).

Approaches regarding the functions of GLP-1, a member of the incretin hormone family, suggest that it acts as an endocrine hormone. GLP-1 modulates glucagon and insulin secretion from pancreatic islets and with other gastrointestinal hormones, contributes to glucose homeostasis and metabolism regulation in healthy individuals (Campbell \& Drucker 2013; Skow et al., 2016). GLP-1 controls saturation and food intake in the gastrointestinal tract. Having an important place in glucose homeostasis, it is a neuropeptide hormone and found in both the central nervous system and the gastrointestinal tract. After food intake, as a response to glucose, stimulates insulin release and inhibits glucagon release. This mechanism is responsible 
for weight loss and glycemic control (Muscogiuri et al., 2017; Calsolaro \& Edison, 2015). The highest L-cell density expressing GLP-1 is in the colon, but nutrients do not reach the colon until after a meal (60 min). Also, the insulin peak occurs after $15 \mathrm{~min}$ (Wichmann et al., 2013).

Tani et al. (2017), fed the rats with Blackcurrant extracts by $5 \mathrm{mg} / \mathrm{kg}$ body weight. Anthocyanin (mostly delphinidine 3-rutinoside) rich blackcurrant extracts were found to ameliorate glucose tolerance by stimulating GLP-1 secretion and inducing insulin secretion. Castro-Acosta et al. (2016), evaluated insulin, blood glucose and incretin concentrations on Men and postmenopausal women by low sugar fruit drinks containing blackcurrant extract providing 150-mg (Low dose), 300-mg (Medium dose) and 600-mg (High dose) total anthocyanins or no blackcurrant extract (Control) immediately before a high-carbohydrate meal. They determined that beverages containing black currant delayed the occurrence of glucose in the blood and decrease the insulin and incretin releasing. The concentration of GLP-1 in blood plasma was increased for $90 \mathrm{~min}$ after 600-mg (High dose) consumption. As a result of the study, it was found that the blackcurrant consumption equivalent to approximately $100 \mathrm{~g}$ reduces incretin, postprandial glycemia, and insulinemia secration. Anthocyanin content of Blackcurrant shows cardio-metabolic health benefits on human metabolism.

\section{Glucose dependent insulinotropic polypeptide (GIP) activity}

Glucose-dependent insulinotropic polypeptide (GIP) is a peptide hormone which expresses the gut. After food intake, it binds to glucose-dependent insulinotropic polypeptide receptors (GIPRs) and became activated. Brain, stomach, adipocytes, pancreatic islets are the different tissues expressing GIPRs. GIP signaling is related with numerous activities, liked overnutrition to obesity, insulin resistance and diabetes. Cho \& Kieffer (2010) reported that GIP intervents in the modulation of $\beta$-cell neogenesis, differentiation, proliferation as well as the stimulation of glucose-stimulated insulin-releasing. Additionally, GIP has extra-pancreatic effects and facilitates insulin secretion. The GIP level is associated with increased visceral fat area (VFA) independent of the effect of low-density lipoprotein and insulin, indicating that GIP is modulating adiposite deposits (Møller et al., 2016). In terms of anthociyanin effects on GIP, Castro-Acosta et al. (2016) determined that, anthocyanin-rich blackcurrant drinks, by the 600-mg (High dose) samples, showed off the inhibitory effect in plasma glucose, and insulin concentrations for $30 \mathrm{~min}$ and GIP concentrations in plasma up to $90 \mathrm{~min}$. reducing postprandial glycemia, insulinemia and incretin secration by GIP suppression, increase the cardio-metabolic health benefits on human metabolism.

\section{Ghrelin activity}

Ghrelin is an orexigenic-hormone, stimulates food intake in a dose-dependent manner, acting centrally and influencing the reward modulation, memory and feeding behavior motivations (Cheung \& Wu, 2013; Monteleone \& Maj, 2013; Wu et al., 2013). It is secreting the glands of the gastric fundus of the endocrine cells, and the gastric body, the duodenum and jejunal mucosa, the lungs, urogenital organs and the pituitary gland (Monteleone \& Maj, 2013). In addition, it acts in the regulation of immune and cardiovascular systems, regulates insulin-like growth factor and plays a dominant role in gastrointestinal system such as gastric emptying and bowel motility (Melissas et al., 2013).

Although ghrelin is still not well-defined in the pathophysiology of obesity, the relationship between increased ghrelin levels and increased appetite has been determined, and the control of the hormone is could be an effective way of treating obesity. In the studies conducted, the problem was determined to be insensitivity or oversensitivity to ghrelin regardless of the consumption of food (Anderson et al., 2013; Dimitriadis et al., 2013). The effects of ghrelin on obesity are evident in studies conducted between obese and slim experimental object comparing ghrelin levels with appetite, although this has not been proven by studies at the molecular level.

\subsection{Role on gut microbiota}

In recent decades, it has well understood that microorganism in the available in the human gut is critical in terms of healthiness. Therefore, the studies focused on the probiotics and the factors which help to their growth and are defined as prebiotics have been increased recently. Diet is a process that acts the gut microbiota and thus the human metabolism. It has been found that obesity can cause different changes in the content of gut microbiota. It has been observed that the mice nourished with the diet containing high-fat were preserved from the diet originated obesity by anthocyanin-rich food (Xie et al., 2018).

On the other hand, the microbiota belonged to the genetically obese mice has been transplanted into the gut of healthy lean mice and observed that the size of adipose tissue increased. Due to the consumption of high-fat diet in mice, obesity and the inflammation in white adipose tissue increased and has been found strong correlation regarding the toll-like receptors and chemokine CCL2.

It has been determined that the consumption of anthocyanins improved the growth of specific fecal bacteria such as Lactobacillus spp. and Enterococcus spp. and the probiotic bacteria such as Bifidobacterium spp. (Hidalgo et al., 2012). The intestinal metabolites of anthocyanins have also beneficial bioactive effects (Xie et al., 2018). A positive correlation has been found between the content of anthocyanin metabolites and the growth of Bifidobacteria (Xie et al., 2018). Obesity could also be affected by intestinal microbiota (Parks et al., 2013). Gastrointestinal microbiomodulator (GIMM) utilization causes to support the specific hormones and increases the intestinal short-chain fatty acid concentrations versus to the control group (Tsuda, 2016).

Anthocyanins could play the role just as prebiotics and affect obesity by promoting intestinal bacterial growth (Jamar et al., 2017). Raphanus sativus (sango sprout) contains cyanidin-based anthocyanins and isothiocyanates. In the regarded diet, the number of microorganisms in the intestine increased compared to the high-fat diet while the number of Enterococcus spp. decreased (Vivarelli et al., 2018). 


\subsection{Bioavailability and bioaccessibility}

Bioavailability and bioaccessibility are the important definitions of the mechanisms that express the absorption and utilization of the anthocyanins by the body. Because it is not possible to digest all the nutritional components after consumption. Furthermore, all of the absorbed components may not give a beneficial reflection on the body organs. Therefore, it is important how much of the body components are beneficial to the body.

Bioavailability is a significant metabolic process that defines the utilization and thus the biodegradability of the dietary nutrients. Bioavailability is an important factor that designates the preventive effect of anthocyanins against diseases (Oracz et al., 2019). Bioavailability is a term that can be expressed as the antioxidant amount that has a biological impact, available in blood and urine, after absorption intestinally. It is a level of ingested component that can show its biological impact when it was included in the systemic circulation in the body.

Bioaccessibility is an outcome measurement of in vitro studies that show the potential impact of dietary antioxidants against diseases. Bioavailability and bioaccessibility $\mathrm{n}$ the body change depending on several factors such as nature of the compound, food matrix, molecular linkage properties, interaction with other compounds, consumed the amount, host-related biological factors, the factors affecting their absorption and intestinal conditions (Porrini \& Riso 2008).

In recent studies, regarding the health benefits of anthocyanins, have mainly been focused on three issues; anthocyanin content in the product, bioavailability, and mechanism of their action. In the systemic circulation, anthocyanins reveal a unique pattern different from flavonoids (Bertoia et al., 2016). The effect of $\mathrm{pH}$ in the human digestion process is significant in terms of synergistic and antagonistic interactions (Braga et al., 2018). Generally, antioxidative compounds exist in glycosylated forms or as esters or polymers, therefore they cannot be absorbed natively, must be hydrolyzed by the specific enzymes before absorption. Even, some antioxidants can reach up to the large intestine without degraded (Stevens et al., 2019; Tao et al., 2019). Exceptionally, anthocyanins in the glycoside chemical form can only be absorbed directly and determined in the systematic circulation (Vendrame \& Klimis-Zacas, 2019). The availability of the phenolic compounds is also affected by the nature of the food matrix, for example, their lipophilic structure limits their solubilization and absorption. Some/Certain solvents as ethanol make absorption of anthocyanins easier through the intestinal epithelium (Kamiloglu et al., 2015). Another factor that can play a role in the interactions is protein some proteins affect the bioavailability of anthocyanins by modifying biological function (Ge et al., 2019). For example, glucose and proteins, except starch, can cause to decrease in the transport efficiency of anthocyanins in the gastric cells (Oliveira et al., 2019). They facilitate the introduction of phenolics into the cell and interact for the absorption (Tungmunnithum et al., 2018).

Regular consumption of fruit and vegetables is important for daily diet. It has been stated that a long consumption period of anthocyanins causes to increase their beneficial effects on the structure of the cells (Tungmunnithum et al., 2018). Inversely, if the duration of the obesity period prolongs, the undesirable changes occur in the metabolism, and, inflammation formed can lead to attenuation of immunity (Caslin \& Hasty, 2019). Estimation of the daily intake value of polyphenols is difficult due to the various biological factors. When considering the whole human metabolism, anthocyanins can affect mechanisms of the homeostasis related to lipids, glucose and amino acids and can suppress the inflammation. In recent years, significant efforts including alternative approaches have been paid to prevent adipogenesis, glucose transport, and intake, to decrease inflammation, and to strengthen the immune response. Anthocyanins are the compounds that have positive effects on gut microbiota and can interact with them. This synergistic effect can help to decrease inflammatory markers associated with many chronic diseases, and also, can support the hormonal balance. Development of obesity causes chronic inflammation accompanied by insulin resistance and therefore, the harmful microorganisms in the gut become dominant (Baldwin et al., 2016). In obese mice fed with polyphenol-rich grape juice have been observed less white adipose tissue and higher glucose tolerance than the mice fed with high-fat content. As a result, it has been found that the grape-based treatments changed the microbiota in the gut and decreased the inflammation probability in the white adipose tissues (Collins et al., 2016).

\section{Anthocyanin-rich fruit and vegetables}

Anthocyanins are compounds that have colors from red to purple. Anthocyanin-rich fruits are could be listed as pomegranate, blackberry, blueberry, goka, blackcurrant, cranberry, aronia, mulberry, sumac drupes, and blood orange; the vegetables are violet cauliflower and red cabbage, and the cereals are black bean and black rice. Health benefits including antioxidant effects of anthocyanins in fruit and vegetables are affected by the various processing technologies such as drying, pasteurization, concentration etc. (Yousuf et al., 2016; Azzini et al., 2017). Significant findings of some anthocyanin-rich fruits and vegetables regarding their health benefits are summarized below.

It has been found that anthocyanin-rich foods are significant in terms of anti-obesity activity. As mentioned by Jiao et al. (2019), consumption of blueberry polyphenol extract reduced body weight and fat accumulation significantly in the obese rats (C57BL/6J) fed by a high-fat diet and has a role as a prebiotic for the gut bacteria. It should be considered that the bioavailability of anthocyanins according to product type (juice, extract, and powdered form) may lead to different results on the weight gain of the test animals. When the fermented blueberry-blackberry beverage mix was used for the feeding rats $(\mathrm{C} 57 \mathrm{BL} / 6 \mathrm{~J})$, the obesity tendency and levels of fasting blood glucose was reduced (Johnson et al., 2016). Similar results were also obtained from the mulberry juice. The mulberry juice provided to decrease the level of blood cholesterol, insulin resistance, and body weight just as blueberry juice. In another study, blueberry juice also decreased the lipid accumulation of the rats (Vendrame et al., 2015).

Anti-inflammatory, antioxidant and cytoprotective effects of blueberry on the obesity pathology have been investigated by Lewis et al. (2018) and Hoskin et al. (2019). Their cytoprotective and anti-inflammatory roles have been explained by the ability 
to replicate the signals including nuclear factor stress and the mitogen activated protein kinase.

According the study conducted by Boušová et al. (2015), the cranberry extract (2\%) was given to obese and non-obese mice for 4 weeks. The plasma thiol content and glutathione S-transferase enzyme function were increased in both groups and, MDA content in the blood was lowered while the enzymes catalase and liver quinone oxidoreductase increased in the obese mice. Raspberry is known with effects on obesity and weight gain (Wu et al., 2018). The rats (C57BL/6) were divided into three experimental groups and fed by three different diets as high-fat enriched with raspberry anthocyanins, only high-fat and low-fat diet for 12 weeks. At the end the body weight gain was found to decrease by about $64 \%$. It was determined that raspberry anthocyanins affected insulin signaling pathway in the obese mice, due to some metabolomics produced. Raspberry anthocyanins found to reduce obesity by alleviation of oxidative stress, regulation of lipid metabolism and amelioration of the gut microbiome (Tu et al., 2018). Also, raspberry extracts have a controlling effect on obesogenic signals in the hepatocytes (Fotschki et al., 2018). The mulberry extract was determined to decrease liver steatosis, adipose hypertrophy and insulin resistance for the subjects fed with the high-fat diet. Yimam et al. (2019) also determined that Morus alba extracts provide appetite suppression, regulation of body weight, and improve metabolic syndrome. It has been observed that black chokeberry (Aronia melanocarpa) led to a decrease in epididymal fat tissue and adiponectin in obese mice (C57BL/6). It has been found that weight gain and obesity can be prevented by this anthocyanin concentrate. Aronia as an anthocyanin-rich fruit was observed to inhibit the fat accumulation in the internal organs and hyperglycemia due to prevention of pancreatic lipase enzyme activity in rats, thereby intestinal lipid absorption can be reduced (Lim et al., 2019). Table grapes, having high content if polyphenols and anthocyanins, determined to be negative metabolic consequences of the high-fat diet (Collins et al., 2016). In a study in which the test animals were used, it was observed that the mice fed with a high-fat diet and the grape stalk, caused to improve glucose tolerance, reduce the inflammation and white adipose tissue formation (Kim et al., 2019). In addition, when the moderate level of fat diet including the grapes was used to feed the test animals, adiposity reduced, the liver triglyceride levels increased and, white adipose tissue inflammatory gene expression decreased moderately (Pérez-Ramírez et al., 2019).

The anthocyanins-rich vegetables as purple colored carrots, potatoes, and maize (Zea mays L.) have significant health benefits including preventing obesity just like anthocyanins-rich fruits. The metabolic syndrome parameters and insulin resistance have been investigated throughout 8 weeks in the obese Zucker rats fed with purple color vegetables (potatoes and carrots) versus the same vegetables without purple color (Ayoub et al., 2017). It has been expressed that the purple vegetables may lead to positive metabolic changes in the test rats having the background of a high-fat diet and obesity. Purple corn can play a role in preventing obesity-associated disorders by mechanisms such as downregulating inflammatory mediators including IL-6, TNF-alpha, COX-2 and IL-1 beta (Tomay et al., 2019). Black carrot (Daucus Carota L.) (Akhtar et al., 2017) and purple maize (Zhang et al.,
$2019 b$ ) have significant roles in metabolic syndrome, Diabetes mellitus, and obesity. Furthermore, black carrot anthocyanins play a role as the major biological components to prevent certain diseases. The feeding with purple sweet potato reduced the fat ratio and the risk factors such as fat deposition and body weight and helped to the regulation of energy expenditure in the obese mice (C57BL/6J) (Ju et al., 2017).

\section{Conclusions}

The fruits including blood orange, pomegranate, mulberry, aronia, berries (blackberry, blackcurrant, cranberry, strawberry, raspberry i.e.), vegetables including red cabbage, purple potatoes, purple carrot, purple cauliflower and red radish, legumes such as black bean and cereals such as black rice are the most known anthocyanin-rich plant foods.

There are five anti-obesity mechanisms that originated from the anthocyanins available in the colored fruits and vegetables. These mechanisms are; inhibition of lipid absorption, increasing energy expenditure, regulation of lipid mechanism, controlling of food intake and regulation of gut microbiota. In medical nutrition therapy, there was a significant impact of anthocyanins on reducing/regulating insulin resistance and fasting insulin levels.

The anti-inflammatory effects of anthocyanins have been explained sufficiently by many researchers. Glucoside-based anthocyanins including delphinidin-3-glucoside, petunidin-3-glucoside, and cyanidin-3-glucoside inhibit mainly F- $\kappa \mathrm{B}$ activities through mitogen-activated protein kinase (MAPK) enzyme (Vendrame et al., 2015). Whereas, cyclooxygenase (COX) enzyme activity is inhibited by cyanidin (Lee et al., 2017).

It can be concluded that the form of fruit or vegetable as anthocyanin source (juice, extract and powdered form) has different effects on fat accumulation in the body. When considering the product type of fruit and vegetable as a source of anthocyanin, different results on the weight gain have been obtained with different fruit and vegetable forms.

\section{References}

Akhtar, S., Rauf, A., Imran, M., Qamar, M., Riaz, M., \& Mubarak, M. S. (2017). Black carrot (Daucus carota L.), dietary and health promoting perspectives of its polyphenols: a review. Trends in Food Science \& Technology, 66, 36-47. http://dx.doi.org/10.1016/j.tifs.2017.05.004.

Anderson, B., Switzer, N. J., Almamar, A., Shi, X., Birch, D. W., \& Karmali, S. (2013). The impact of laparoscopic sleeve gastrectomy on plasma ghrelin levels: a systematic review. Obesity Surgery, 23(9), 1476-1480. http://dx.doi.org/10.1007/s11695-013-0999-7. PMid:23794092.

Andre, C. M., Oufir, M., Guignard, C., Hoffmann, L., Hausman, J. F., Evers, D., \& Larondelle, Y. (2007). Antioxidant profiling of native Andean potato tubers (Solanum tuberosum L.) reveals cultivars with high levels of $\beta$-carotene, $\alpha$-tocopherol, chlorogenic acid, and petanin. Journal of Agricultural and Food Chemistry, 55(26), 10839-10849. http://dx.doi.org/10.1021/jf0726583. PMid:18044831.

Aronoff, S. L., Berkowitz, K., Shreiner, B., \& Want, L. (2004). Glucose metabolism and regulation: beyond insulin and glucagon. Diabetes Spectrum, 17(3), 183-190. http://dx.doi.org/10.2337/diaspect.17.3.183.

Ayoub, H. M., McDonald, M. R., Sullivan, J. A., Tsao, R., Platt, M., Simpson, J., \& Meckling, K. A. (2017). The effect of anthocyanin- 
rich purple vegetable diets on metabolic syndrome in obese Zucker rats. Journal of Medicinal Food, 20(12), 1240-1249. http://dx.doi. org/10.1089/jmf.2017.0025. PMid:28956702.

Azzini, E., Giacometti, J., \& Russo, G. L. (2017). Antiobesity effects of anthocyanins in preclinical and clinical studies. Oxidative Medicine and Cellular Longevity, 2017, 2017. http://dx.doi.org/10.1155/2017/2740364. PMid:28785373.

Baldwin, J., Collins, B., Wolf, P. G., Martinez, K., Shen, W., Chuang, C. C., Zhong, W., Cooney, P., Cockrell, C., Chang, E., Gaskins, H. R., \& McIntosh, M. K. (2016). Table grape consumption reduces adiposity and markers of hepatic lipogenesis and alters gut microbiota in butter fat-fed mice. The Journal of Nutritional Biochemistry, 27, 123-135. http://dx.doi.org/10.1016/j.jnutbio.2015.08.027. PMid:26423887.

Belwal, T., Nabavi, S. F., Nabavi, S. M., \& Habtemariam, S. (2017). Dietary anthocyanins and insulin resistance: When food becomes a medicine. Nutrients, 9(10), 1111. http://dx.doi.org/10.3390/ nu9101111. PMid:29023424.

Benn, T., Kim, B., Park, Y.-K., Wegner, C. J., Harness, E., Nam, T.G., Kim, D.-O., Lee, J. S., \& Lee, J.-Y. (2014). Polyphenol-rich blackcurrant extract prevents inflammation in diet-induced obese mice. The Journal of Nutritional Biochemistry, 25(10), 1019-1025. http://dx.doi.org/10.1016/j.jnutbio.2014.05.008. PMid:25034502.

Bertoia, M. L., Rimm, E. B., Mukamal, K. J., Hu, F. B., Willett, W. C., \& Cassidy, A. (2016). Dietary flavonoid intake and weight maintenance: three prospective cohorts of 124,086 US men and women followed for up to 24 years. BMJ, 352, i17. http://dx.doi.org/10.1136/bmj.i17. PMID: 26823518.

Bhaswant, M., Fanning, K., Netzel, M., Mathai, M. L., Panchal, S. K., \& Brown, L. (2015). Cyanidin 3-glucoside improves diet-induced metabolic syndrome in rats. Pharmacological Research, 102, 208217. http://dx.doi.org/10.1016/j.phrs.2015.10.006. PMid:26477387.

Bonetta, R. (2018). Potential Therapeutic Applications of MnSODs and SOD-Mimetics. Chemistry (Weinheim an der Bergstrasse, Germany), 24(20), 5032-5041. http://dx.doi.org/10.1002/chem.201704561. PMid:29131419.

Boušová, I., Bártíková, H., Matoušková, P., Lněničková, K., Zappe, L., Valentová, K., Szotáková, B., Martin, J., \& Skálová, L. (2015). Cranberry extract-enriched diets increase NAD (P) H: quinone oxidoreductase and catalase activities in obese but not in nonobese mice. Nutrition Research (New York, N.Y.), 35(10), 901-909. http:// dx.doi.org/10.1016/j.nutres.2015.08.002. PMid:26319613.

Braga, A. R. C., Murador, D. C., de Souza Mesquita, L. M., \& de Rosso, V. V. (2018). Bioavailability of anthocyanins: Gaps in knowledge, challenges and future research. Journal of Food Composition and Analysis, 68, 31-40. http://dx.doi.org/10.1016/j.jfca.2017.07.031.

Budić-Leto, I., Mucalo, A., Ljubenkov, I., \& Zdunić, G. (2018). Anthocyanin profile of wild grape Vitis vinifera in the eastern Adriatic region. Scientia Horticulturae, 238, 32-37. http://dx.doi. org/10.1016/j.scienta.2018.04.036.

Bukhari, S. A., Farah, N., Mustafa, G., Mahmood, S., \& Naqvi, S. A. R. (2019). Magneto-Priming Improved Nutraceutical Potential and Antimicrobial Activity of Momordica charantia L. Without Affecting Nutritive Value. Applied Biochemistry and Biotechnology, 188(3), 878-892. http://dx.doi.org/10.1007/s12010-019-02955-w. PMid:30729394.

Calsolaro, V., \& Edison, P. (2015). Novel GLP-1 (glucagon-like peptide-1) analogues and insulin in the treatment for Alzheimer's disease and other neurodegenerative diseases. CNS Drugs, 29(12), 1023-1039. http://dx.doi.org/10.1007/s40263-015-0301-8. PMid:26666230.
Campbell, J. E., \& Drucker, D. J. (2013). Pharmacology, physiology, and mechanisms of incretin hormone action. Cell Metabolism, 17(6), 819837. http://dx.doi.org/10.1016/j.cmet.2013.04.008. PMid:23684623.

Caslin, H. L., \& Hasty, A. H. (2019). Extrinsic and intrinsic immunometabolism converge: perspectives on future research and therapeutic development for obesity. Current Obesity Reports, 8(3), 210-19. http://dx.doi.org/10.1007/s13679-019-00344-2. PMid:30919312.

Castro-Acosta, M. L., Smith, L., Miller, R. J., McCarthy, D. I., Farrimond, J. A., \& Hall, W. L. (2016). Drinks containing anthocyanin-rich blackcurrant extract decrease postprandial blood glucose, insulin and incretin concentrations. The Journal of Nutritional Biochemistry, 38, 154-161. http://dx.doi.org/10.1016/j.jnutbio.2016.09.002. PMid:27764725.

Chen, Z., Wang, C., Pan, Y., Gao, X., \& Chen, H. (2018). Hypoglycemic and hypolipidemic effects of anthocyanins extract from black soybean seed coat in high fat diet and streptozotocin-induced diabetic mice. Food \& Function, 9(1), 426-439. http://dx.doi.org/10.1039/ C7FO00983F. PMid:29220052.

Cheng, D. M., Pogrebnyak, N., Kuhn, P., Poulev, A., Waterman, C., Rojas-Silva, P., Johnson, W. D., \& Raskin, I. (2014). Polyphenolrich Rutgers Scarlet Lettuce improves glucose metabolism and liver lipid accumulation in diet-induced obese C57BL/6 mice. Nutrition (Burbank, Los Angeles County, Calif.), 30(7-8, Suppl), S52-S58. http:// dx.doi.org/10.1016/j.nut.2014.02.022. PMid:24985107.

Cheung, C. K., \& Wu, J. C. Y. (2013). Role of ghrelin in the pathophysiology of gastrointestinal disease. Gut and Liver, 7(5), 505-512. http://dx.doi. org/10.5009/gnl.2013.7.5.505. PMid:24073306.

Cho, Y. M., \& Kieffer, T. J. (2010). K-cells and glucose-dependent insulinotropic polypeptide in health and disease. Vitamins and Hormones, 84, 111-150. http://dx.doi.org/10.1016/B978-0-12381517-0.00004-7. PMid:21094898.

Chuang, C. C., Shen, W., Chen, H., Xie, G., Jia, W., Chung, S., \& McIntosh, M. K. (2012). Differential effects of grape powder and its extract on glucose tolerance and chronic inflammation in high-fatfed obese mice. Journal of Agricultural and Food Chemistry, 60(51), 12458-12468. http://dx.doi.org/10.1021/jf3028107. PMid:23210691.

Clifford, M. N. (2000). Anthocyanins-nature, occurrence and dietary burden. Journal of the Science of Food and Agriculture, 80(7), 1063-1072. http://dx.doi.org/10.1002/(SICI)1097-0010(20000515)80:7<1063::AIDJSFA605>3.0.CO;2-Q.

Collins, B., Hoffman, J., Martinez, K., Grace, M., Lila, M. A., Cockrell, C., Nadimpalli, A., Chang, E., Chuang, C. C., Zhong, W., Mackert, J., Shen, W., Cooney, P., Hopkins, R., \& McIntosh, M. (2016). A polyphenol-rich fraction obtained from table grapes decreases adiposity, insulin resistance and markers of inflammation and impacts gut microbiota in high-fat-fed mice. The Journal of Nutritional Biochemistry, 31, 150-165. http://dx.doi.org/10.1016/j. jnutbio.2015.12.021. PMid:27133434.

Delgado-Vargas, F., \& Paredes-Lopez, O. (2002). Natural colorants for food and nutraceutical uses. CRC press. http://dx.doi. org/10.1201/9781420031713.

Dimitriadis, E., Daskalakis, M., Kampa, M., Peppe, A., Papadakis, J. A., \& Melissas, J. (2013). Alterations in gut hormones after laparoscopic sleeve gastrectomy: a prospective clinical and laboratory investigational study. Annals of Surgery, 257(4), 647-654. http://dx.doi.org/10.1097/ SLA.0b013e31826e1846. PMid:23108120.

Dziadek, K., Kopeć, A., \& Piątkowska, E. (2019). Intake of fruit and leaves of sweet cherry beneficially affects lipid metabolism, oxidative stress and inflammation in Wistar rats fed with high fat-cholesterol diet. Journal of Functional Foods, 57, 31-39. http://dx.doi.org/10.1016/j. jff.2019.03.044. 
Esposito, D., Damsud, T., Wilson, M., Grace, M. H., Strauch, R., Li, X., Lila, M. A., \& Komarnytsky, S. (2015). Black currant anthocyanins attenuate weight gain and improve glucose metabolism in diet-induced obese mice with intact, but not disrupted, gut microbiome. Journal of Agricultural and Food Chemistry, 63(27), 6172-6180. http://dx.doi. org/10.1021/acs.jafc.5b00963. PMid:26066489.

Fascella, G., D’Angiolillo, F., Mammano, M. M., Amenta, M., Romeo, F. V., Rapisarda, P., \& Ballistreri, G. (2019). Bioactive compounds and antioxidant activity of four rose hip species from spontaneous sicilian flora. Food Chemistry, 289, 56-64. http://dx.doi.org/10.1016/j. foodchem.2019.02.127. PMid:30955649.

Fotschki, B., Laparra, J., \& Sójka, M. (2018). Raspberry Polyphenolic Extract Regulates Obesogenic Signals in Hepatocytes. Molecules (Basel, Switzerland), 23(9), 2103. http://dx.doi.org/10.3390/ molecules23092103. PMid:30134638.

Frueh, J., Maimari, N., Homma, T., Bovens, S. M., Pedrigi, R. M., Towhidi, L., \& Krams, R. (2013). Systems biology of the functional and dysfunctional endothelium. Cardiovascular Research, 99(2), 334-341. http://dx.doi.org/10.1093/cvr/cvt108. PMid:23650287.

Garcia, D., \& Shaw, R. J. (2017). AMPK: mechanisms of cellular energy sensing and restoration of metabolic balance. Molecular Cell, 66(6), 789-800. http://dx.doi.org/10.1016/j.molcel.2017.05.032. PMid:28622524.

Ge, J., Yue, X., Wang, S., Chi, J., Liang, J., Sun, Y., Gao, X., \& Yue, P. (2019). Nanocomplexes composed of chitosan derivatives and $\beta$-Lactoglobulin as a carrier for anthocyanins: Preparation, stability and bioavailability in vitro. Food Research International, 116, 336-345. http://dx.doi.org/10.1016/j.foodres.2018.08.045. PMid:30716954.

Gonçalves, A. C., Rodrigues, M., Santos, A., Alves, G., \& Silva, L. (2018). Antioxidant status, antidiabetic properties and effects on Caco- 2 cells of colored and non-colored enriched extracts of sweet cherry fruits. Nutrients, 10(11), 1688. http://dx.doi.org/10.3390/ nu10111688. PMid:30400658.

Habtemariam, S., \& Varghese, K. (2014). The antidiabetic therapeutic potential of dietary polyphenols. Current Pharmaceutical Biotechnology, 15(4), 391-400. http://dx.doi.org/10.2174/13892010156661406171 04643. PMid:24938887.

Hidalgo, M., Oruna-Concha, M. J., Kolida, S., Walton, G. E., Kallithraka, S., Spencer, J. P. E., Gibson, G. R., \& de Pascual-Teresa, S. (2012). Metabolism of anthocyanins by human gut microflora and their influence on gut bacterial growth. Journal of Agricultural and Food Chemistry, 60(15), 3882-3890. http://dx.doi.org/10.1021/jf3002153. PMid:22439618.

Hoskin, R. T., Xiong, J., Esposito, D. A., \& Lila, M. A. (2019). Blueberry polyphenol-protein food ingredients: the impact of spray drying on the in vitro antioxidant activity, anti-inflammatory markers, glucose metabolism and fibroblast migration. Food Chemistry, 280, 187-194. http://dx.doi.org/10.1016/j.foodchem.2018.12.046. PMid:30642485.

Hwang, Y. P., Choi, J. H., Han, E. H., Kim, H. G., Wee, J.-H., Jung, K. O., Jung, K. H., Kwon, K., Jeong, T. C., Chung, Y. C., \& Jeong, H. G. (2011). Purple sweet potato anthocyanins attenuate hepatic lipid accumulation through activating adenosine monophosphateactivated protein kinase in human HepG2 cells and obese mice. Nutrition Research (New York, N.Y.), 31(12), 896-906. http://dx.doi. org/10.1016/j.nutres.2011.09.026. PMid:22153515.

Iizuka, Y., Ozeki, A., Tani, T., \& Tsuda, T. (2018). Blackcurrant extract ameliorates hyperglycemia in type 2 diabetic mice in association with increased basal secretion of glucagon-like peptide- 1 and activation of AMP-activated protein kinase. Journal of Nutritional Science and Vitaminology, 64(4), 258-264. http://dx.doi.org/10.3177/jnsv.64.258. PMid:30175788.
Jamar, G., Estadella, D., \& Pisani, L. P. (2017). Contribution of anthocyanin-rich foods in obesity control through gut microbiota interactions. BioFactors (Oxford, England), 43(4), 507-516. http:// dx.doi.org/10.1002/biof.1365. PMid:28504479.

Jeong, H. S., Hong, S. J., Lee, T.-B., Kwon, J.-W., Jeong, J. T., Joo, H. J., Park, J. H., Ahn, C.-M., Yu, C. W., \& Lim, D.-S. (2014). Effects of black raspberry on lipid profiles and vascular endothelial function in patients with metabolic syndrome. Phytotherapy Research, 28(10), 1492-1498. http://dx.doi.org/10.1002/ptr.5154. PMid:24706588.

Jiao, X., Wang, Y., Lin, Y., Lang, Y., Li, E., Zhang, X., Zhang, Q., Feng, Y., Meng, X., \& Li, B. (2019). Blueberry polyphenols extract as a potential prebiotic with anti-obesity effects on C57BL/6 J mice by modulating the gut microbiota. The Journal of Nutritional Biochemistry, 64, 88100. http://dx.doi.org/10.1016/j.jnutbio.2018.07.008. PMid:30471564.

Johnson, M. H., Wallig, M., Luna Vital, D. A., \& de Mejia, E. G. (2016). Alcohol-free fermented blueberry-blackberry beverage phenolic extract attenuates diet-induced obesity and blood glucose in C57BL/6J mice. The Journal of Nutritional Biochemistry, 31, 45-59. http://dx.doi.org/10.1016/j.jnutbio.2015.12.013. PMid:27133423.

Ju, J.-H., Yoon, H.-S., Park, H.-J., Kim, M.-Y., Shin, H.-K., Park, K.-Y., Yang, J.-O., Sohn, M.-S., \& Do, M.-S. (2011). Anti-obesity and antioxidative effects of purple sweet potato extract in 3T3-L1 adipocytes in vitro. Journal of Medicinal Food, 14(10), 1097-1106. http://dx.doi.org/10.1089/jmf.2010.1450. PMid:21861722.

Ju, R., Zheng, S., Luo, H., Wang, C., Duan, L., Sheng, Y., Zhao, C., Xu, W., \& Huang, K. (2017). Purple sweet potato attenuate weight gain in high fat diet induced obese mice. Journal of Food Science, 82(3), 787-793. http://dx.doi.org/10.1111/1750-3841.13617. PMid:28135399.

Kalita, D., Holm, D. G., LaBarbera, D. V., Petrash, J. M., \& Jayanty, S. S. (2018). Inhibition of $\alpha$-glucosidase, $\alpha$-amylase, and aldose reductase by potato polyphenolic compounds. PLoS One, 13(1), e0191025. http://dx.doi.org/10.1371/journal.pone.0191025. PMid:29370193.

Kamiloglu, S., Capanoglu, E., Grootaert, C., \& Van Camp, J. (2015). Anthocyanin absorption and metabolism by human intestinal Caco-2 cells-A review. International Journal of Molecular Sciences, 16(9), 21555-21574. http://dx.doi.org/10.3390/ijms160921555. PMid:26370977.

Kanamoto, Y., Yamashita, Y., Nanba, F., Yoshida, T., Tsuda, T., Fukuda, I., Nakamura-Tsuruta, S. (2011). A black soybean seed coat extract prevents obesity and glucose intolerance by up-regulating uncoupling proteins and down-regulating inflammatory cytokines in high-fat diet-fed mice. Journal of Agricultural and Food Chemistry, 59(16), 8985-8993. http://dx.doi.org/10.1021/jf201471p. PMid:21751816.

Kang, J. S. (2018). Theoretical model and characteristics of mitochondrial thermogenesis. Biophysics Reports, 4(2), 63-67. http://dx.doi. org/10.1007/s41048-018-0054-2. PMid:29756006.

Kasote, D. M., Duncan, G. J., Neacsu, M., \& Russell, W. R. (2019). Rapid method for quantification of anthocyanidins and anthocyanins in human biological samples. Food Chemistry, 290, 56-63. http://dx.doi. org/10.1016/j.foodchem.2019.03.109. PMid:31000056.

Khoo, H. E., Azlan, A., Tang, S. T., \& Lim, S. M. (2017). Anthocyanidins and anthocyanins: colored pigments as food, pharmaceutical ingredients, and the potential health benefits. Food \& Nutrition Research, 61(1), 1361779. http://dx.doi.org/10.1080/16546628.201 7.1361779. PMid:28970777.

Kim, B. M., Cho, B. O., \& Jang, S. I. (2019). Muscat Bailey A grape stalk extract ameliorates high-fat diet-induced obesity by downregulating PPAR $\gamma$ and $\mathrm{C} / \mathrm{EPBa}$ in mice. International Journal of Molecular Medicine, 43(1), 489-500. PMid:30365044.

Kim, S., Hong, J., Jeon, R., \& Kim, H. S. (2016). Adzuki bean ameliorates hepatic lipogenesis and proinflammatory mediator expression in 
mice fed a high-cholesterol and high-fat diet to induce nonalcoholic fatty liver disease. Nutrition Research (New York, N.Y.), 36(1), 90-100. http://dx.doi.org/10.1016/j.nutres.2015.11.002. PMid:26773785.

Krassas, G. E., Kelestimur, F., Micic, D., Tzotzas, T., Konstandinidis, T., Bougoulia, M., Tsametis, C., Colak, R., Jorga, J., Kostic, Z., \& Pavlovic, M., \& Balkan Group for the Study of Obesity (2003). Self-reported prevalence of obesity among 20,329 adults from large territories of Greece, Serbia and Turkey. Hormones (Athens, Greece), 2(1), 4954. http://dx.doi.org/10.14310/horm.2002.1182. PMid:17003002.

Lazar, D. F., \& Saltiel, A. R. (2006). Lipid phosphatases as drug discovery targets for type 2 diabetes. Nature Reviews. Drug Discovery, 5(4), 333-342. http://dx.doi.org/10.1038/nrd2007. PMid:16582877.

Lee, C.-Y., Lee, C.-H., Tsai, S., Huang, C.-T., Wu, M.-T., Tai, S.-Y., Lin, F.-F., Chao, N.-C., \& Chang, C.-J. (2009). Association between serum leptin and adiponectin levels with risk of insulin resistance and impaired glucose tolerance in non-diabetic women. The Kaohsiung Journal of Medical Sciences, 25(3), 116-125. http://dx.doi.org/10.1016/ S1607-551X(09)70050-6. PMid:19419916.

Lee, J. H., Lim, J. D., \& Choung, M. G. (2013). Studies on the anthocyanin profile and biological properties from the fruits of Acanthopanax senticosus (Siberian Ginseng). Journal of Functional Foods, 5(1), 380-388. http://dx.doi.org/10.1016/j.jff.2012.11.010.

Lee, N. K., Cheon, C. J., \& Rhee, J. K. (2018). Anti-obesity effect of red radish coral sprout extract by inhibited triglyceride accumulation in a microbial evaluation system and in high-fat diet-induced obese mice. Journal of Microbiology and Biotechnology, 28(3), 397-400. http://dx.doi.org/10.4014/jmb.1802.02005. PMid:29539876.

Lee, Y. M., Yoon, Y., Yoon, H., Park, H. M., Song, S., \& Yeum, K. J. (2017). Dietary anthocyanins against obesity and inflammation. Nutrients, 9(10), 1089. http://dx.doi.org/10.3390/nu9101089. PMid:28974032.

Lemecha, M., Morino, K., Imamura, T., Iwasaki, H., Ohashi, N., Ida, S., Sato, D., Sekine, O., Ugi, S., \& Maegawa, H. (2018). MiR-494-3p regulates mitochondrial biogenesis and thermogenesis through PGC1-a signalling in beige adipocytes. Scientific Reports, 8(1), 15096. http://dx.doi.org/10.1038/s41598-018-33438-3. PMid:30305668.

Lewis, E. D., Ren, Z., DeFuria, J., Obin, M. S., Meydani, S. N., \& Wu, D. (2018). Dietary supplementation with blueberry partially restores T-cell-mediated function in high-fat-diet-induced obese mice. British Journal of Nutrition, 119(12), 1393-1399. http://dx.doi.org/10.1017/ S0007114518001034. PMid:29845904.

Li, W., Chen, S., Zhou, G., Li, H., Zhong, L., \& Liu, S. (2018). Potential role of cyanidin 3-glucoside $(\mathrm{C} 3 \mathrm{G})$ in diabetic cardiomyopathy in diabetic rats: an in vivo approach. Saudi Journal of Biological Sciences, 25(3), 500-506. http://dx.doi.org/10.1016/j.sjbs.2016.11.007. PMid:29686513.

Liang, L., Liu, X., He, J., Shao, Y., Liu, J., Wang, Z., Xia, L., Han, T., \& Wu, P. (2019). Cyanidin-3-glucoside induces mesenchymal to epithelial transition via activating Sirt1 expression in triple negative breast cancer cells. Biochimie, 162, 107-115. http://dx.doi.org/10.1016/j. biochi.2019.03.004. PMid:30876970.

Lim, S.-M., Lee, H. S., Jung, J. I., Kim, S. M., Kim, N. Y., Seo, T. S., Bae, J.-S., \& Kim, E. J. (2019). Cyanidin-3-O-galactoside-enriched Aronia melanocarpa extract attenuates weight gain and adipogenic pathways in high-fat diet-induced obese C57BL/6 mice. Nutrients, 11(5), 1190. http://dx.doi.org/10.3390/nu11051190. PMid:31137884.

Long, H. L., Zhang, F. F., Wang, H. L., Yang, W. S., Hou, H. T., Yu, J. K., \& Liu, B. (2018). Mulberry anthocyanins improves thyroid cancer progression mainly by inducing apoptosis and autophagy cell death. The Kaohsiung Journal of Medical Sciences, 34(5), 255-262. http:// dx.doi.org/10.1016/j.kjms.2017.11.004. PMid:29699632.
Meier, J. J., \& Nauck, M. A. (2005). Glucagon-like peptide 1 (GLP-1) in biology and pathology. Diabetes/Metabolism Research and Reviews, 21(2), 91-117. http://dx.doi.org/10.1002/dmrr.538. PMid:15759282.

Melissas, J., Leventi, A., Klinaki, I., Perisinakis, K., Koukouraki, S., de Bree, E., \& Karkavitsas, N. (2013). Alterations of global gastrointestinal motility after sleeve gastrectomy: a prospective study. Annals of Surgery, 258(6), 976-982. http://dx.doi.org/10.1097/ SLA.0b013e3182774522. PMid:23160151.

Møller, C. L., Vistisen, D., Færch, K., Johansen, N. B., Witte, D. R., Jonsson, A., Pedersen, O., Hansen, T., Lauritzen, T., Jørgensen, M. E., Torekov, S. S., \& Holst, J. J. (2016). Glucose-dependent insulinotropic polypeptide is associated with lower low-density lipoprotein but unhealthy fat distribution, independent of insulin: the ADDITION-PRO Study. The Journal of Clinical Endocrinology and Metabolism, 101(2), 485-493. http://dx.doi.org/10.1210/jc.20153133. PMid:26505824.

Monteleone, P., \& Maj, M. (2013). Dysfunctions of leptin, ghrelin, BDNF and endocannabinoids in eating disorders: beyond the homeostatic control of food intake. Psychoneuroendocrinology, 38(3), 312-330. http://dx.doi.org/10.1016/j.psyneuen.2012.10.021. PMid:23313276.

Muscogiuri, G., DeFronzo, R. A., Gastaldelli, A., \& Holst, J. J. (2017). Glucagon-like peptide-1 and the central/peripheral nervous system: crosstalk in diabetes. Trends in Endocrinology and Metabolism, 28(2), 88-103. http://dx.doi.org/10.1016/j.tem.2016.10.001. PMid:27871675.

Nemes, A., Homoki, J. R., Kiss, R., Hegedűs, C., Kovács, D., Peitl, B., Gál, F., Stündl, L., Szilvássy, Z., \& Remenyik, J. (2019). Effect of anthocyanin-rich tart cherry extract on inflammatory mediators and adipokines involved in Type 2 diabetes in a high fat diet induced obesity mouse model. Nutrients, 11(9), 1966. http://dx.doi. org/10.3390/nu11091966. PMid:31438590.

Oliveira, H., Perez-Gregório, R., de Freitas, V., Mateus, N., \& Fernandes, I. (2019). Comparison of the in vitro gastrointestinal bioavailability of acylated and non-acylated anthocyanins: purple-fleshed sweet potato vs red wine. Food Chemistry, 276, 410-418. http://dx.doi. org/10.1016/j.foodchem.2018.09.159. PMid:30409613.

Oracz, J., Nebesny, E., Zyzelewicz, D., Budryn, G., \& Luzak, B. (2019). Bioavailability and metabolism of selected cocoa bioactive compounds: a comprehensive review. Critical Reviews in Food Science and Nutrition, 1-39. In press. http://dx.doi.org/10.1080/10408398.201 9.1619160. PMid:31124371.

Overall, J., Bonney, S. A., Wilson, M., Beermann, A., Grace, M. H., Esposito, D., Lila, M. A., \& Komarnytsky, S. (2017). Metabolic effects of berries with structurally diverse anthocyanins. International Journal of Molecular Sciences, 18(2), 422. http://dx.doi.org/10.3390/ ijms18020422. PMid:28212306.

Pan, W. W., \& Myers, M. G. Jr. (2018). Leptin and the maintenance of elevated body weight. Nature Reviews. Neuroscience, 19(2), 95-105. http://dx.doi.org/10.1038/nrn.2017.168. PMid:29321684.

Park, C. H., Kim, J. H., Lee, E. B., Hur, W., Kwon, O. J., Park, H. J., \& Yoon, S. K. (2017). Aronia melanocarpa extract ameliorates hepatic lipid metabolism through PPAR $\gamma 2$ downregulation. PLoS One, 12(1), e0169685. http://dx.doi.org/10.1371/journal.pone.0169685. PMid:28081181.

Park, S., Kang, S., Jeong, D. Y., Jeong, S. Y., Park, J. J., \& Yun, H. S. (2015). Cyanidin and malvidin in aqueous extracts of black carrots fermented with Aspergillus oryzae prevent the impairment of energy, lipid and glucose metabolism in estrogen-deficient rats by AMPK activation. Genes \& Nutrition, 10(2), 455. http://dx.doi.org/10.1007/ s12263-015-0455-5. PMid:25701199.

Parks, B. W., Nam, E., Org, E., Kostem, E., Norheim, F., Hui, S. T., Pan, C., Civelek, M., Rau, C. D., Bennett, B. J., Mehrabian, M., 
Ursell, L. K., He, A., Castellani, L. W., Zinker, B., Kirby, M., Drake, T. A., Drevon, C. A., Knight, R., Gargalovic, P., Kirchgessner, T., Eskin, E., \& Lusis, A. J. (2013). Genetic control of obesity and gut microbiota composition in response to high-fat, high-sucrose diet in mice. Cell Metabolism, 17(1), 141-152. http://dx.doi.org/10.1016/j. cmet.2012.12.007. PMid:23312289.

Perez-Meseguer, J., Torres-González, L., Gutiérrez-González, J. A., Alarcón-Galván, G., Zapata-Chavira, H., Waksman-de Torres, N., Moreno-Peña, D. P., Muñoz-Espinosa, L. E., \& Cordero-Pérez, P. (2019). Anti-inflammatory and nephroprotective activity of Juglans mollis against renal ischemia-reperfusion damage in a Wistar rat model. BMC Complementary and Alternative Medicine, 19(1), 186. http://dx.doi.org/10.1186/s12906-019-2604-7. PMid:31349827.

Pérez-Ramírez, I. F., de Diego, E. H., Riomoros-Arranz, M., ReynosoCamacho, R., Saura-Calixto, F., \& Pérez-Jiménez, J. (2019). Effects of acute intake of grape/pomegranate pomace dietary supplement on glucose metabolism and oxidative stress in adults with abdominal obesity. International Journal of Food Sciences and Nutrition, 71(1), 94-105. PMid:31062633.

Porrini, M., \& Riso, P. (2008). Factors influencing the bioavailability of antioxidants in foods: a critical appraisal. Nutrition, Metabolism, and Cardiovascular Diseases: NMCD, 18(10), 647-650. http://dx.doi. org/10.1016/j.numecd.2008.08.004.

Poudyal, H., Panchal, S., \& Brown, L. (2010). Comparison of purple carrot juice and $\beta$-carotene in a high-carbohydrate, high-fat diet-fed rat model of the metabolic syndrome. British Journal of Nutrition, 104(9), 1322-1332. http://dx.doi.org/10.1017/S0007114510002308. PMid:20619064.

Reboredo-Rodríguez, P. (2018). Potential roles of berries in the prevention of breast cancer progression. Journal of Berry Research, 8(4), 1-17. http://dx.doi.org/10.3233/JBR-180366.

Roh, E., \& Kim, M. S. (2016). Brain regulation of energy metabolism. Endocrinology and Metabolism (Seoul, Korea), 31(4), 519-524. http:// dx.doi.org/10.3803/EnM.2016.31.4.519. PMid:28029023.

Sardo, C. L., Kitzmiller, J. P., Apseloff, G., Harris, R. B., Roe, D. J., Stoner, G. D., \& Jacobs, E. T. (2016). An open-label randomized crossover trial of lyophilized black raspberries on postprandial inflammation in older overweight males: a pilot study. American Journal of Therapeutics, 23(1), e86-e91. http://dx.doi.org/10.1097/ MJT.0b013e3182a40bf8. PMid:23982695.

Sato, D., Kusunoki, M., Seino, N., Nishina, A., Feng, Z., Tsutsumi, K., \& Nakamura, T. (2015). Black soybean extract reduces fatty acid contents in subcutaneous, but not in visceral adipose triglyceride in high-fat fed rats. International Journal of Food Sciences and Nutrition, 66(5), 539-545. http://dx.doi.org/10.3109/09637486.20 15.1028907. PMid:25830948.

Scazzocchio, B., Vari, R., Filesi, C., D’Archivio, M., Santangelo, C., Giovannini, C., Iacovelli, A., Silecchia, G., Volti, G. L., Galvano, F., \& Masella, R. (2011). Cyanidin-3-O- $\beta$-glucoside and protocatechuic acid exert insulin-like effects by upregulating PPAR $\gamma$ activity in human omental adipocytes. Diabetes, 60(9), 2234-2244. http:// dx.doi.org/10.2337/db10-1461. PMid:21788573.

Skow, M. A., Bergmann, N. C., \& Knop, F. K. (2016). Diabetes and obesity treatment based on dual incretin receptor activation:'twincretins'. Diabetes, Obesity \& Metabolism, 18(9), 847-854. http://dx.doi. org/10.1111/dom.12685. PMid:27160961.

Ştefănescu (Braic), R., Vari, C., Imre, S., Huţanu, A., Fogarasi, E., Todea, T., Groşan, A., Eşianu, S., Laczkó-Zöld, E., \& Dogaru, M. (2018). Vaccinium Extracts as Modulators in Experimental Type 1 Diabetes. Journal of Medicinal Food, 21(11), 1106-1112. http:// dx.doi.org/10.1089/jmf.2017.0141. PMid:29847743.

Stevens, Y., Rymenant, E. V., Grootaert, C., Camp, J. V., Possemiers, S., Masclee, A., \& Jonkers, D. (2019). The intestinal fate of citrus flavanones and their effects on gastrointestinal health. Nutrients, 11(7), 1464. http://dx.doi.org/10.3390/nu11071464. PMid:31252646.

Stull, A. J. (2016). Blueberries' impact on insulin resistance and glucose intolerance. Antioxidants, 5(4), 44. http://dx.doi.org/10.3390/ antiox5040044. PMid:27916833.

Tani, T., Nishikawa, S., Kato, M., \& Tsuda, T. (2017). Delphinidin 3rutinoside-rich blackcurrant extract ameliorates glucose tolerance by increasing the release of glucagon-like peptide-1 secretion. Food Science \& Nutrition, 5(4), 929-933. http://dx.doi.org/10.1002/ fsn3.478. PMid:28748082.

Tao, W., Zhang, Y., Shen, X., Cao, Y., Shi, J., Ye, X., \& Chen, S. (2019). Rethinking the mechanism of the health benefits of proanthocyanidins: absorption, metabolism, and interaction with gut microbiota. Comprehensive Reviews in Food Science and Food Safety, 18(4), 971-985. https://doi.org/10.1111/1541-4337.12444.

Tomay, F., Marinelli, A., Leoni, V., Caccia, C., Matros, A., Mock, H.-P., Tonelli, C., \& Petroni, K. (2019). Purple corn extract induces longlasting reprogramming and $\mathrm{M} 2$ phenotypic switch of adipose tissue macrophages in obese mice. Journal of Translational Medicine, 17(1), 237. http://dx.doi.org/10.1186/s12967-019-1972-6. PMid:31337415.

Tsuda, T. (2016). Recent progress in anti-obesity and anti-diabetes effect of berries. Antioxidants, 5(2), 13. http://dx.doi.org/10.3390/ antiox5020013. PMid:27058561.

Tu, P., Bian, X., Chi, L., Gao, B., Ru, H., Knobloch, T. J., Weghorst, C. M., \& Lu, K. (2018). Characterization of the functional changes in mouse gut microbiome Associated with Increased Akkermansia muciniphila Population Modulated by Dietary Black Raspberries. ACS Omega, 3(9), 10927-10937. http://dx.doi.org/10.1021/acsomega.8b00064. PMid:30288460.

Tucakovic, L., Colson, N., Santhakumar, A. B., Kundur, A. R., Shuttleworth, M., \& Singh, I. (2018). The effects of anthocyanins on body weight and expression of adipocyte's hormones: Leptin and adiponectin. Journal of Functional Foods, 45, 173-180. http://dx.doi.org/10.1016/j. jff.2018.03.042.

Tungmunnithum, D., Thongboonyou, A., Pholboon, A., \& Yangsabai, A. (2018). Flavonoids and other phenolic compounds from medicinal plants for pharmaceutical and medical aspects: An overview. Medicines (Basel, Switzerland), 5(3), 93. http://dx.doi.org/10.3390/ medicines5030093. PMid:30149600.

Turturică, M., Oancea, A., Râpeanu, G., \& Bahrim, G. (2015). Anthocyanins: naturally occuring fruit pigments with functional properties. The Annals of the University Dunarea de Jos of Galati. Fascicle VI, Food Technology, 39(1)

Vendrame, S., \& Klimis-Zacas, D. (2019). Potential factors influencing the effects of anthocyanins on blood pressure regulation in humans: a review. Nutrients, 11(6), 1431. http://dx.doi.org/10.3390/nu11061431. PMid:31242638.

Vendrame, S., Zhao, A., Merrow, T., \& Klimis-Zacas, D. (2015). The effects of wild blueberry consumption on plasma markers and gene expression related to glucose metabolism in the obese Zucker rat. Journal of Medicinal Food, 18(6), 619-624. http://dx.doi.org/10.1089/ jmf.2014.0065. PMid:25383490.

Vijayaraj, P., Nakagawa, H., \& Yamaki, K. (2019). Cyanidin and cyanidin-3glucoside derived from Vigna unguiculata act as noncompetitive inhibitors of pancreatic lipase. Journal of Food Biochemistry, 43(3), e12774. http://dx.doi.org/10.1111/jfbc.12774. PMid:31353559.

Vivarelli, F., Canistro, D., Babot Marquillas, C., Cirillo, S., De Nicola, G. R., Iori, R., Biagi, G., Pinna, C., Gentilini, F., Pozzo, L., Longo, V., \& Paolini, M. (2018). The combined effect of Sango sprout juice and caloric restriction on metabolic disorders and gut microbiota composition in an obesity model. International Journal of Food Sciences and Nutrition, 69(2), 192-204. http://dx.doi.org/10.1080/ 09637486.2017.1350940. PMid:28770644. 
Wang, L., Li, Y. M., Lei, L., Liu, Y., Wang, X., Ma, K. Y., \& Chen, Z. Y. (2015). Cranberry anthocyanin extract prolongs lifespan of fruit flies. Experimental Gerontology, 69, 189-195. http://dx.doi.org/10.1016/j. exger.2015.06.021. PMid:26159161.

Watson, A. W., Okello, E. J., Brooker, H. J., Lester, S., McDougall, G. J., \& Wesnes, K. A. (2019). The impact of blackcurrant juice on attention, mood and brain wave spectral activity in young healthy volunteers. Nutritional Neuroscience, 22(8), 596-606. http://dx.doi. org/10.1080/1028415X.2017.1420539. PMid:29343201.

Wichmann, A., Allahyar, A., Greiner, T. U., Plovier, H., Lundén, G. Ö., Larsson, T., Drucker, D. J., Delzenne, N. M., Cani, P. D., \& Bäckhed, F. (2013). Microbial modulation of energy availability in the colon regulates intestinal transit. Cell Host \& Microbe, 14(5), 582-590. http://dx.doi.org/10.1016/j.chom.2013.09.012. PMid:24237703.

Wilson, T., Luebke, J. L., Morcomb, E. F., Carrell, E. J., Leveranz, M. C., Kobs, L., Schmidt, T. P., Limburg, P. J., Vorsa, N., \& Singh, A. P. (2010). Glycemic responses to sweetened dried and raw cranberries in humans with type 2 diabetes. Journal of Food Science, 75(8), H218-H223. http://dx.doi.org/10.1111/j.1750-3841.2010.01800.x. PMid:21535498.

World Health Organization - WHO. (2018). Guideline: healthtopics, obesity. Geneva: WHO.

Wu, T., Jiang, Z., Yin, J., Long, H., \& Zheng, X. (2016a). Anti-obesity effects of artificial planting blueberry (Vaccinium ashei) anthocyanin in high-fat diet-treated mice. International Journal of Food Sciences and Nutrition, 67(3), 257-264. http://dx.doi.org/10.3109/09637486 2016.1146235. PMid:26899872.

Wu, T., Yin, J., Zhang, G., Long, H., \& Zheng, X. (2016b). Mulberry and cherry anthocyanin consumption prevents oxidative stress and inflammation in diet-induced obese mice. Molecular Nutrition \& Food Research, 60(3), 687-694. http://dx.doi.org/10.1002/mnfr.201500734. PMid:26627062.

Wu, T., Qi, X., Liu, Y., Guo, J., Zhu, R., Chen, W., Zheng, X., \& Yu, T. (2013). Dietary supplementation with purified mulberry (Morus australis Poir) anthocyanins suppresses body weight gain in highfat diet fed C57BL/6 mice. Food Chemistry, 141(1), 482-487. http:// dx.doi.org/10.1016/j.foodchem.2013.03.046. PMid:23768383.

Wu, T., Tang, Q., Yu, Z., Gao, Z., Hu, H., Chen, W., Zheng, X., \& Yu, T. (2014). Inhibitory effects of sweet cherry anthocyanins on the obesity development in C57BL/6 mice. International Journal of Food Sciences and Nutrition, 65(3), 351-359. http://dx.doi.org/10.3109/0 9637486.2013.854749. PMid:24224922.

Wu, T., Yang, L., Guo, X., Zhang, M., Liu, R., \& Sui, W. (2018). Raspberry anthocyanin consumption prevents diet-induced obesity by alleviating oxidative stress and modulating hepatic lipid metabolism. Food \& Function, 9(4), 2112-2120. http://dx.doi.org/10.1039/C7FO02061A. PMid:29632909.

Xie, L., Lee, S. G., Vance, T. M., Wang, Y., Kim, B., Lee, J.-Y., Chun, O. K., \& Bolling, B. W. (2016). Bioavailability of anthocyanins and colonic polyphenol metabolites following consumption of aronia berry extract. Food Chemistry, 211, 860-868. http://dx.doi.org/10.1016/j. foodchem.2016.05.122. PMid:27283706.

Xie, L., Su, H., Sun, C., Zheng, X., \& Chen, W. (2018). Recent advances in understanding the anti-obesity activity of anthocyanins and their biosynthesis in microorganisms. Trends in Food Science \& Technology, 72, 13-24. http://dx.doi.org/10.1016/j.tifs.2017.12.002.

Yang, H., Tian, T., Wu, D., Guo, D., \& Lu, J. (2019). Prevention and treatment effects of edible berries for three deadly diseases: Cardiovascular disease, cancer and diabetes. Critical Reviews in Food Science and Nutrition, 59(12), 1903-1912. http://dx.doi.org/1 0.1080/10408398.2018.1432562. PMid:29381386.
Yimam, M., Jiao, P., Hong, M., Brownell, L., Lee, Y.-C., Kim, H.-J., Nam, J.-B., Kim, M.-R., \& Jia, Q. (2019). Morus alba, A Medicinal Plant for Appetite Suppression and Weight Loss. Journal of Medicinal Food, 22(7), 741-751. http://dx.doi.org/10.1089/jmf.2017.0142. PMid:31120370.

Yousuf, B., Gul, K., Wani, A. A., \& Singh, P. (2016). Health benefits of anthocyanins and their encapsulation for potential use in food systems: a review. Critical Reviews in Food Science and Nutrition, 56(13), 2223-2230. http://dx.doi.org/10.1080/10408398.2013.805 316. PMid:25745811.

Zhang, H., Koes, R., Shang, H., Fu, Z., Wang, L., Dong, X., Zhang, J., Passeri, V., Li, Y., Jiang, H., Gao, J., Li, Y., Wang, H., \& Quattrocchio, F. M. (2019a). Identification and functional analysis of three new anthocyanin R2R3-MYB genes in Petunia. Plant Direct, 3(1), e00114. http://dx.doi.org/10.1002/pld3.114. PMid:31245756.

Zhang, Q., Gonzalez de Mejia, E., Luna-Vital, D., Tao, T., Chandrasekaran, S., Chatham, L., Juvik, J., Singh, V., \& Kumar, D. (2019b). Relationship of phenolic composition of selected purple maize (Zea mays L.) genotypes with their anti-inflammatory, anti-adipogenic and antidiabetic potential. Food Chemistry, 289, 739-750. http://dx.doi. org/10.1016/j.foodchem.2019.03.116. PMid:30955674.

Zhang, J., Sun, L., Dong, Y., Fang, Z., Nisar, T., Zhao, T., Wang, Z.C., \& Guo, Y. (2019c). Chemical compositions and $\alpha$-glucosidase inhibitory effects of anthocyanidins from blueberry, blackcurrant and blue honeysuckle fruits. Food Chemistry, 299, 125102. http:// dx.doi.org/10.1016/j.foodchem.2019.125102. PMid:31279126.

Zhang, Y., Niu, F., Sun, J., Xu, F., \& Yue, R. (2015). Purple sweet potato (Ipomoea batatas L.) color alleviates high-fat-diet-induced obesity in SD rat by mediating leptin's effect and attenuating oxidative stress. Food Science and Biotechnology, 24(4), 1523-1532. http://dx.doi. org/10.1007/s10068-015-0196-7.

Zhao, L., Zou, T., Gomez, N. A., Wang, B., Zhu, M. J., \& Du, M. (2018). Raspberry alleviates obesity-induced inflammation and insulin resistance in skeletal muscle through activation of AMP-activated protein kinase (AMPK) a1. Nutrition \& Diabetes, 8(1), 39. http:// dx.doi.org/10.1038/s41387-018-0049-6. PMid:29961765.

Žilić, S., Dodig, D., Vančetović, J., Grčić, N., Perić, V., Titan, P., \& Maksimović, V. (2019). Composition of anthocyanins in colored grains and the relationship of their non-acylated and acylated derivatives. Polish Journal of Food and Nutrition Sciences, 69(2), 137-146. https://doi.org/10.31883/pjfns/105100.

\section{Abbreviations}

BMI: Body mass index

LDL: Low density lipoprotein

GIMM: Gastrointestinal microbiome modulator

CPT1A: Carnitine palmitoyltransferase-1A

SREBP1c: Sterol regulatory element binding protein-1c

PPAR $\gamma$ : Peroxisomal proliferator-activated receptor gamma

AMPK: 5'Adenosine monophosphate-activated protein kinase

ACC1: Acetyl-CoA carboxylase

FAS: Fatty acid synthase

TNF- $\alpha$ : Tumor necrosis factor alpha

NF- $\kappa$ B: Nuclear factor kappa B 